\title{
JANINA STANKIEWICZ HANNA BORTNOWSKA \\ Professional image creation by students on social media sites (in the light of empirical research)
}

Prof. Janina Stankiewicz University of Zielona Gora Hanna Bortnowska, Ph.D. University of Zielona Gora

\section{Introduction}

Shaping the image, referred to in the literature as self-presentation (cf. Białopiotrowicz 2010; Szmajke 2001a; Wosińska 2004), can be achieved "by controlling information: about oneself, about other people, views, ideas, results and motives of action, plans and intentions, disclosed by a person to their surroundings" (Szmajke 2001a, p. 147)1. Due to the fact that people assume different social roles, they also have different types of images (such as parent, wife/husband, colleague, supervisor, friend, employer, member of association, professional or religious group). All these images overlap. In the following article, emphasis has been placed on the professional type of image of an individual. It is important in the process of seeking employment, being still a subject of debate by various researchers dealing with these issues (Ingold, Kleinmann, König, Melchers 2015; e.g.: Jansen, König, Stadelmann, Kleinmann 2012; Lievens, Peeters 2008; Sackett, Lievens 2008).

1 Self-presentation is sometimes identified with unethical actions - impression manipulation, controlling the way others see us (cf. Leary 1999). 
Professional image is not generally identified only with physical appearance as it constitutes a narrow understanding of the term. Rather, it encompasses one's hard and soft professional competences (including knowledge and skills with respect to self-presentation, their use in practice), motives of one's actions, values and attitudes one practices and manifests, behavior exhibited in the real and the virtual world (cf. Białopiotrowicz 2010; Kowalska, Łakoma, Szymoniuk 2011; Królik 2004). It is further shaped - positively or negatively - by third parties. They can do this either directly (by issuing recommendations, references, comments) or indirectly (by exhibiting socially frowned-upon behavior in the professional group one is part of, promoting, e.g. in the media, information regarding: one's profession, degrees held, industry in which one works, one's current/former employer] (figure 1$)^{2}$.

The creation of the desired image is therefore not an easy task. It requires self-discipline, perseverance and consistency in the implementation of various actions undertaken not only in the real world (cf. e.g.: Stankiewicz, Bortnowska 2016), but also in the virtual one. The latter is what the following article focuses on. This is because the Internet is an essential, integral part of the reality in which we live, and virtual space (including social media ${ }^{3}$ ) is a place where we create our own image - not only in the eyes of friends, but also potential employers, recruiters ${ }^{4}$, contractors, etc. Active participation in social media facilitates maintaining relationships with current, former or future collaborators, providing opportunities to stand out in a given industry, getting to know persons that make it up, as well as finding out about latest

2 Image is also an important factor in interpersonal relations established in private and professional life. A. Szmajke (2001b, p. 148) states that: „self-presentational behavior favour a proper conduct of interpersonal interactions by facilitating swift communication between partners as to its nature (...), to mutual expectations about the role assumed in the interaction, to wishes and desires with regard to mutual treatment by the participants of the interaction".

3 Social networking sites (e.g.: Facebook, LinkedIn, GoldenLine, Profeo, Twitter, Nk.pl, Instagram, Fotka.pl, MySpace, Grono.net, Blip.pl) are "a kind of online communities grouped within a specific website, whose users satisfy the need for contact with other people by exchanging information, experiences and interests" (Szewczyk 2011, p. 382).

4 In the era of universal digitization, for many people dealing with job recruitment and selection, the Internet has become an everyday tool and source of information about potential candidates. The survey carried out in 2014 (among over 600 people responsible for recruitment in Central and Eastern Europe, Russia, the Middle East and North Africa) by a human resource company, Adecco, shows that more than half of respondents used social media to verify the competences of job applicants (http://www.adecco.pl/dlamediow/rekrutacja-na-portalach-spo\%C5\%82eczno\%C5\%9Bciowych. aspx, date of access: 07.08.2015). 
professional trends. It also makes it possible to conduct the so-called passive job searching. Presentation of one's professional profile in the social network in a substantial, coherent and appealing way, or setting up an interesting web page including one's professional achievements, may encourage potential employers and headhunters to submit job offers, initiate professional and business relationships.

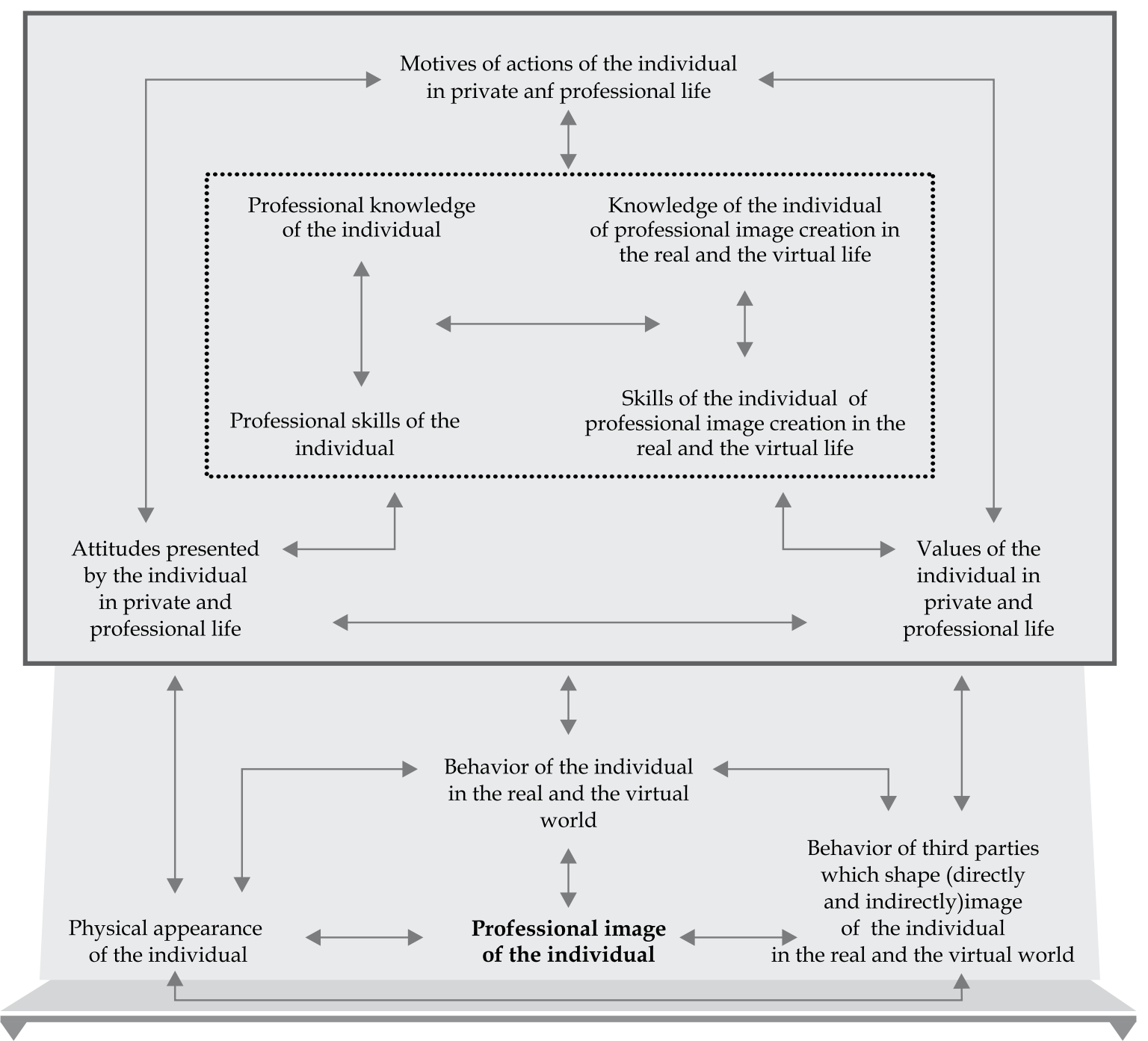

Figure 1. Professional image of the individual in the real and the virtual world; indicators

Source: own study 
The aim of this article is to identify actions undertaken by young job market participants, associated with creating one's professional image on social media. In order to achieve this goal, empirical research was conducted in 2015. The survey involved students of the Faculty of Economics and Management at the University of Zielona Gora.

\section{Actions conducive to creating a positive professional image on social media}

Online screening, i.e. checking what the Internet "says" about us, is becoming a trend noticeable not only among Polish employers, constituting an important element of job applicants verification process (Broughton, Foley, Ledermaier, Cox 2013; Kuo-Huie Chiang, Hung-Yue 2015; Rusak, Wizerunek w sieci...). Wanting to make sure of making the right decision, employers examine not only the information published on the Internet by the candidate themselves, but also opinions on them posted online by third parties. Potential sources of information about employees include: search engines, social media (including business ones), candidates' websites or blogs. Based on the analysis of the information thus obtained, recruiters formulate conclusions regarding the reliability of job applicants, their lifestyle, attitudes toward employers or individuals.

In order to form their opinions on the candidate, employers become silent observers of their behavior expressed by means of the Internet, including social media [connecting not only individuals (e.g. Facebook), but also business people, employers, business partners, headhunters etc. (e.g. LinkedIn, GoldenLine)]. They not only analyze information contained in a candidate's profile (including achievements at various stages of their career), but simultaneously verify their activity regarding interpersonal relations, development of knowledge and professional and non-professional interests and sharing them with other users. Recruiters, among others: check lists included in one's circle of friends, read one's comments and views presented on discussion forums, blogs, status updates, published photos, links, videos, etc ${ }^{5}$. On this basis, they examine the image of candidates not only as individuals, but participants of the job market as well. With this in mind, candidates must consciously develop a positive professional image online. Conducive to this is professional presentation of strengths as an employee $^{6}$ in one's profile, e.g. including real rather than laconic information about

5 For more information on the actions undertaken by social media users, see e.g.: P. Frankowski,

A. Juneja (2009), U. Grześkowiak (2011), A. Szewczyk (2011).

6 Promoting one's own profile, e.g. in other social media sites, blogs or one's personal or company website, is also of significant importance. 
one's qualifications, experience and professional skills, using keywords ${ }^{7}$ related to the job, the industry or one's professional interests; changing one's profile standard website address (i.e. generated automatically by the website, consisting of a string of alphanumeric characters) to the dedicated one (i.e. containing the profile owner's full name $)^{8}$. Similarly helpful is practical demonstration of one's skills required for a particular job or profession, e.g. through active participation in industry forums and discussion groups, prompting others to potential solutions to the problems they face, presenting statements (e.g. via blogs/miniblogs) about one's professional interests, and publishing links that are associated with them. Creating a positive professional image is further enhanced by having one's skills confirmed by other users of social media, former employers or colleagues, by means of issuing recommendations that point to the professionalism of a candidate and mention fruitful cooperation with their participation. One should also keep an eye on the profile of a potential employer as it can communicate that an individual has been for some time striving to establish cooperation on professional grounds.

Building an appealing professional image in the virtual world is also favored by adherence to netiquette (i.e. network etiquette). One should therefore avoid posting comments revealing lack of professionalism (e.g. posts containing swear words, touching upon controversial issues) as well as amateur photos and videos which "should not see the light of day", etc. ${ }^{9}$ It is also important not to spam other Internet users, or flood them (i.e. send identical messages in short time intervals), not to publish comments unrelated to the thread topic, not to start new discussion threads without checking first if the issue has not been already brought up or explained in the list of frequently asked questions (FAQ), not to overuse emojis, etc. Such behavior can effectively discourage potential employers from inviting a candidate to participate in the selection process, and as a result - make it difficult for one to find a job. Similar results will be generated by introducing entries during working hours, posting negative comments about employers, coworkers, contractors and individuals, as well as controversial behavior that is

7 Thanks to such keywords (e.g. names of diplomas, certificates), it is easier to find people claiming to possess command of certain languages or certificates of completed courses of study, training, etc. 8 Presenting one's photo on a social media site, one needs to pay attention to its professional look, namely it is better to avoid selfies or holiday photos).

9 D. Bohnert and W.H. Ross (2010) found, based on their research, that unprofessional behavior can significantly reduce a candidate's chances of finding a job or result in the employer's offering them a job position at a lower wage. 
considered socially unacceptable (e.g. racism, aggression, the so-called hating ${ }^{10}$ ). What types of behavior, with regard to creating one's own professional image, were exhibited by the surveyed students in 2012-2015 on social media sites? This question has been answered later in the article.

\section{Research methodology and characteristics of the research sample}

The research took into account the opinions of 181 randomly selected from full-time and part-time students of the Faculty of Economics and Management at the University of Zielona Gora. The direct survey technique was opted for, using a categorized and standardized questionnaire which contained, among others, 18 questions: closed and semi-open (single and multiple choice). The following scales were used: ordinal scale (unipolar and bipolar), position scale and Likert scale. The questionnaire also included socio-demographic variables characterizing the respondents.

Among the research participants, the majority were women (71\%). Most of them $(82 \%)$ were under 25 years old. They studied toward one of the four following degrees: Management (42.5\%), Economy (23.5\%), National Security $(19.5 \%)$ and Logistics $(13.5 \%)$. A fifth of respondents $(20 \%)$ were graduate students, the rest $(80 \%)$ were undergraduate.

Let us add that $42 \%$ of the respondents were not employed. The vast majority $(88 \%)$ of the remaining respondents were employed on executive positions, rather than managerial $(12 \%)$. More than half $(56 \%)$ signed a contract of employment, a quarter (27\%) signed a commission contract (Polish: umowa zlecenie / o dzieło), while few $(6.5 \%)$ were employed on the basis of a permanent work contract. Some respondents $(7.5 \%)$ worked without signing any contract with their employer. Only a small percentage of the respondents $(3 \%)$ ran their own business.

Every forth (26.5\%) employed research participant worked in a micro enterprise; the same number were part of small businesses. A similar proportion of the respondents $(28 \%)$ were employed in a large company, while one in five $(19 \%)$ - in a medium-sized company. Some part of the respondents $(21 \%$ and $19 \%$, respectively) worked in organizations engaged in wholesale and retail trade or public administration and national defense. One in ten $(10.5 \%)$ worked

10 Hating means presenting such "statements that are aggressive, exceed the limits of cultural expression, but at the same time do not meet the conditions necessary to qualify them as hate speech" (Włodarczyk 2014, p. 3). 
in industrial processing or in a financial agency. Few of the respondents $(8.5 \%)$ admitted to working in hotels or restaurants. Others (approx. 30\% in total), less frequently, represented companies operating in other sectors (e.g. construction or transport-related, storage and communications).

The research sample thus comprised mostly women of less than 25 years of age; undergraduate students of the Faculty of Economics and Management at the University of Zielona Gora. Many of them were not employed, and if they were, these were usually executive positions based on a contract of employment in a micro enterprise or small company engaged in wholesale and retail trade, or public administration and national defense.

\section{Actions aimed at building a positive professional image in social media in the practice of the surveyed students}

The research shows that the majority of the respondents (93\%) had, or created, at least one profile on a social media in the analyzed period (2012-2015). Most of them $(87.5 \%)$ were active users on a daily basis. Almost one in ten (approx. 9\%) checked the profile a few times a week, while it was seldom (approx. 3.5\%) for the students to do it less frequently. What actions did the survey participants take on the analyzed websites? What was their purpose?

Most people had a profile on Facebook (90.6\%) and/or NK.pl (nearly 40\%, $91.7 \%$ in total). Both services bring together people with the main goal of establishing and/or maintaining private relationships as well as sharing content with other people, be it thoughts, photos, music, life events, interests, etc. Other social networking sites were significantly less popular among the respondents: Instagram (13.8\%), Fotka.pl (8.3\%), Twitter (5.5\%), GoldenLine (3.9\%), MySpace (3.3\%), LinkedIn (1.7\%). Consequently, the actions of the students usually focused on establishing and/or maintaining social interpersonal relationships, expanding their knowledge of the subjects that are not work-related and/or sharing it with other users of social media. It was rare for them to undertake strictly career-management efforts, develop business relationships (recall that only $5.5 \%$ of the participants ${ }^{11}$ had profiles on GoldenLine or LinkedIn, while none of the surveyed students set up a profile on Profeo). Therefore, many missed

11 These were the people with at least one year of professional experience and, therefore, those who might have already achieved their first professional successes and were able to present them to potential employers. 
the opportunity to create a positive professional image, and thus significantly reduced their chances of finding a job through social media.

Information presented in Table 1 indicates that the respondents were primarily concerned with establishing and maintaining private relationships, as well as sharing knowledge of non-professional subjects with their friends. For this purpose, they e.g. created their own user profile (88.1\%), searched their friends $(90.5 \%)$ and sent them short messages $(89.9 \%)$. Also common was reading comments posted by their friends (81\%), "liking" their posts, status updates, shared links (77.4\%), as well as uploading their own photos $(66.7 \%)$. The respondents also shared information about their non-business interests by "liking" celebrity fan pages (45.2\%), promoting music among friends $(42.3 \%)$ or sharing links from the scope of their hobbies (29.2\%). They also published longer texts about their own interests, mainly on discussion forums and thematic groups (31\%), less commonly (5.4\%) in the form of a (mini)blog.

The analysis results showed that the respondents rarely undertook activities aimed at shaping their professional image in the virtual world ${ }^{12}$. It is worth recalling that only $5.5 \%$ of the respondents had their own professional profiles ${ }^{13}$. The majority (94.5\%) missed - consciously or not - the opportunity to draw attention of people responsible for recruitment process to the information on their education, experience and professional successes, training, skills or interests.

Table 1. Actions of the surveyed students on social media sites

\begin{tabular}{l|c}
\hline \multicolumn{1}{c|}{ Actions of the surveyed students on social networking sites } & $\begin{array}{c}\text { \% of } \\
\text { answers }\end{array}$ \\
\hline \multicolumn{2}{c}{$\begin{array}{l}\text { Establishing and/or maintaining private social interpersonal relationships; expanding } \\
\text { knowledge of not work-related subjects and/or sharing it with other users of social media }\end{array}$} \\
\hline 1. Finding and creating a list of friends & 90,5 \\
\hline 2. Sending private messages & 89,9 \\
\hline 3. Creating a user profile & 88,1
\end{tabular}

12 Due to the small number of people taking action focused on shaping their own professional image, analysis examining variables that characterize the respondents was abandoned.

13 The research scope did not account for the content of the respondents' profiles on social networking sites. 


\begin{tabular}{l|c} 
4. Reading other people's (friends') comments & 81,0 \\
\hline 5. "Liking” (posts, links, status updates published by friends or strangers) & 77,4 \\
\hline 6. Uploading own photos & 66,7 \\
\hline 7. Sharing opinions/comments relating to those of friends & 60,7 \\
\hline 8. Reading other people's (i.e. not friends') comments & 51,8 \\
\hline 9. Publishing status updates & 48,8 \\
\hline 10. „Liking” celebrity fan pages & 45,2 \\
\hline 11. Sharing songs & 42,3 \\
\hline 12. Writing on discussion forums and thematic groups (about private life, hobbies) & 31,0 \\
\hline 13. Creating and participating in events & 30,4 \\
\hline 14. Sharing links of not work-related nature & 29,2 \\
\hline 15. Sharing short videos from private life & 8,3 \\
\hline 16. Running a (mini)blog dedicated to non-professional interests & 5,4 \\
\hline Establishing and/or maintaining professional relationships; career development and expanding \\
\hline knowledge of professional subjects and/or sharing it with other users of social media
\end{tabular}

Source: own study based on research results

Almost half (47\%) "liked" (i.e., inter alia, approved as positive) fan pages of organizations/brands/ employers. Some people sought jobs (38.7\%) or 
checked information about potential employers (23.3\%) through social media. Every fifth respondent $(22 \%)$ used social networking sites to expand their knowledge of professional interests and/or share it with other users of social media by actions such as sharing links (19.6\%) or publishing statements on discussion forums and thematic groups (17.3\%) associated with these interests (although none of the respondents run their own professional blog). Publishing work-related posts on social networking sites could be assessed positively probably by those employers who expect from their potential employees considerable skills in the field of communication, knowledge sharing, building interpersonal relationships. Such competences could also be demonstrated by the respondents, who - as mentioned - published well-researched posts on discussion forums and thematic groups related to their hobbies, those sharing interesting links of non-professional nature, or those running a (mini) blog dedicated to an intriguing, popular, or on the contrary - niche, topic. These activities, although not directly related in to career management, could nevertheless encourage employers to establish professional cooperation with the surveyed students.

Given that communication and publishing professionally edited statements are competencies sought after by many employers, it becomes important to answer the following question: did the surveyed students take this into account when presenting their views to other users of social media? It was found that almost half of the respondents (48.8\%) declared they always cared about the correct form and structure of their statements while communicating with others on social networks. Over $40 \%$ of the people said they made it often or very often, and only few (approx. 10\% in total) admitted to only occasionally, or hardly ever, pay attention to grammar and spelling of their entries. From our own experience of cooperating with students - that is, that associated with communicating with them online - follows that some of them make mistakes in spelling and punctuation. They are often the result of fast typing, e.g. lack of Polish letters, missing punctuation marks. It also happened that students would overuse emojis and acronyms, failed to use polite phrases (or chose them improperly), left messages unsigned (sometimes sending blank messages when they were accompanied by attachments). The positive side of this is that, upon bringing to their attention the negative consequences of ineffective online communication, they avoided duplicating the errors.

Also identified were actions of the surveyed students that were negatively affecting their professional image. It was examined, among others, whether they published online negative opinions about people they were familiar 
with, in either private or professional life. It was established that one in ten respondents admitted to expressing negative opinions about their workplace $(10.4 \%)$, their boss $(8.9 \%)$ and/or co-workers $(11.11 \%)$. Rarely $(5.9 \%)$ such action was taken against contractors, but more often $(16 \%)$ against private individuals. Those respondents were not accounting for various consequences of hate speech $^{14}$, or the so-called "hating". It is known that abusive, vulgar and offensive comments on the Internet, regarding people one is familiar with in private and professional life, negatively affect the professional image of their authors and discourage employers to hire or continue working with such persons in their organization. Currently, this issue is becoming especially significant since - as mentioned - employers increasingly verify online information about job applicants ${ }^{15}$. Apart from that, some of the surveyed students16 sent strangers friend requests or accepted such requests coming from other people (potentially also recruiters).

\section{Conclusion}

Creating a positive professional image, both in the real world as well as the virtual one, is important in the job search process. It is worth taking conscious action to present oneself to potential employers in such a way as to be perceived as someone who would be useful and well-suited to their businesses.

14 According to S. Eodziński (2003, p. 5), hate speech refers to „oral and written statements and iconic presentations abusing, accusing, deriding and degrading groups and individuals for reasons partly beyond their control - such as racial ethnicity, religious affiliation, and also sex, sexual preference, disability or the fact of belonging to a natural social group, e.g. inhabitants of a certain territory, representatives of a particular profession, speakers of a certain language. It is a well-publicized violent verbal expression, expression of collective hatred, addressed to natural communities determined by race, nationality, gender and religion, affiliation with which does not stem from freely chosen beliefs."

15 They can not only search for information using the Google search engine or browse profiles and statements posted on social networking sites. There are also search engines that aggregate information from different websites and allow for comprehensive online search with the goal of obtaining the most extensive information about specific individuals (e.g. szuku.pl, pipl.pl. wyczajka. com) (Wieman 2009).

$167 \%$ often admitted strangers (i.e. persons unknown in private life, in the real world) to the circle of their friends on social networking sites, 5\% - sometimes. One in four (25\%) respondents admitted to do it rarely. Most of them (63\%), however, claimed to never accept a friend request from a stranger. 
Building a positive professional image is fostered by professional, thoughtful behavior on social networking sites. Information posted on these websites should not create a false image of a job market participant. It is better to present one's actual strengths pointing to a significant professional potential, making one stand out from other job applicants.

The vast majority of the surveyed students had profiles on websites that facilitate establishing private relationships (mostly coming down to searching friends, sending them private messages, exchanging comments, photos), developed non-professional interests and/or shared their knowledge in this field with other users of social media (e.g. by "liking" celebrity fan pages, publishing statements on discussion forums and thematic groups, sharing music, sharing links related to one's hobbies). On the other hand, far less frequently, actions of the surveyed students on social networking sites related to shaping their own professional image, which may indicate deficits in knowledge of the possibilities of creating a professional image through social media. Actions of some of the respondents - including, but not limited to: "liking" fan pages of organizations/ brands/employers, conducting job search and sharing links of work-related nature - must be considered insufficient for creating a positive professional image on social networking sites. It is perhaps worth familiarizing young participants in the job market with several measures to improve their professional image in social media and thus increase their chances on the job market:

- partaking in internships, training, odd jobs, engaging in the activities of student organizations or NGOs in order to gain experience and put into practice the knowledge obtained during studies; such information can be later included in a professionally prepared profile on a social networking site (preferably LinkedIn, Profeo, GoldenLine etc.),

- professional presentation in one's professional profile their actual strengths as an employee (using keywords), systematically updating the profile,

- publishing only professionally taken photographs on one's professional profile,

- changing the standard profile Internet address (automatically generated by the website) to the dedicated one,

- active participation in industry forums and discussion groups, prompting others to potential solutions to the problems they face,

- publishing longer texts (e.g. via blogs) about one's interests, especially those work-related,

- publishing substantial, balanced and linguistically correct entries,

- sharing links relating to one's professional interests,

- ensuring that one's skills are confirmed by other users of social media, as 
well as obtaining positive recommendations from former employers or coworkers,

- observing the profile of a potential employer on social media,

- adhering to netiquette (avoiding unprofessional behavior, including e.g. "hating", flooding, spamming),

- avoiding the overuse of emojis etc.

The positive image should be looked after not only by employees, persons seeking employment, but also employers. Employer branding still remains an important topic analyzed by theorists and practitioners of management. It takes on particular significance in view of today's growing demographic decline, increasing specialization of professions and globalization. One-time recruitment actions are insufficient to "attract" talented workers. What is needed is a long-term strategy, the aim of which would be to build a unique and strong employer brand, which will facilitate establishing a team of competent employees within the organization.

\section{Summary}

Professional image creation by students on social media sites (in the light of empirical research)

Internet has become an important way of our image creation, including the professional one. By participating in social media, it is possible to shape our own image not only in eyes of private persons, but also of potential employers. The aim of the article is to identify activities which were undertaken by young participants in labour market (students) associated with creating their own professional image in social media. It was found that they usually concentrated on shaping private relationships, as well as the development of their knowledge of the subjects which were not connected with work or job and also on sharing that knowledge with other users of social media. In contrast, much less attention they paid on creating their own professional image and the development of their careers.

Keywords: professional image, social media.

\section{Streszczenie}

Kreowanie wizerunku zawodowego przez studentów w serwisach społecznościowych (w świetle badań empirycznych).

Internet stał się ważnym sposobem kreowania własnego wizerunku, w tym zawodowego. Poprzez uczestnictwo 
w serwisach społecznościowych można budować swój obraz nie tylko w oczach osób prywatnych, ale i potencjalnych pracodawców. Celem artykułu jest identyfikacja działań podejmowanych przez młodych uczestników rynku pracy (studentów) związanych $\mathrm{z}$ kreowaniem swojego wizerunku zawodowego w serwisach społecznościowych. Ustalono, że koncentrowali się oni na budowaniu relacji prywatnych, rozwoju swojej wiedzy na tematy pozazawodowe i/lub na dzieleniu się nią z innymi użytkownikami social media. Natomiast znacznie mniej uwagi poświęcali kreowaniu własnego wizerunku zawodowego i rozwojowi swoich karier.

\section{Słowa}

kluczowe: wizerunek zawodowy, serwisy społecznościowe.

\section{References}

1. Białopiotrowicz G. (2010), Kreowanie wizerunku w biznesie i polityce, Poltext, Warszawa.

2. Bohnert D., Ross W.H. (2010), The Influence of Social networking Web Sites on the Evaluation of Job Candidates, "Cyperpsychology, Behaviour, and Social Networking", Vol. 13, Issue 3, pp. 341-347.

3. Broughton A., Foley B., Ledermaier S., Cox A. (2013), The use of social media in the recruitment process, Institute for Employment Studies, Brighton.

4. Frankowski P., Juneja A. (2009), Serwisy społecznościowe. Budowa, administracja i modernizacja, Helion, Gliwice.

5. Grześkowiak U. (2011), Portale społecznościowe - wybrane aspekty, Zeszyty Naukowe Uniwersytetu Szczecińskiego, "Studia Informatica” No. 28, Szczecin, pp. 359-367.

6. http://www.adecco.pl/dlamediow/rekrutacja-na-portalachspo \% C5\%82eczno\% C5\%9Bciowych.aspx (07.08.2015 r. - date of access).

7. Ingold P.V., Kleinmann M., König C.J., Melchers K.G. (2015), Shall we Continue or Stop Disapproving of Self-Presentation? Evidence on Impression Management and Faking in a Selection Context and their Relation to Job Performance, "European Journal of Work and Organizational Psychology", No. 24 (3), pp. 420-432.

8. Jansen A., König C. J., Stadelmann E. H., Kleinmann M. (2012), Applicants' self-presentational behaviour: What do recruiters expect and what do they get?, "Journal of Personnel Psychology", Vol. 11 (2), pp. 77-85.

9. Kowalska K., Łakoma A., Szymoniuk B. (2011), Wizerunek biznesowy, Politechnika Lubelska, Lublin.

10. Królik G. (2004), Autoprezentacja, Wydawnictwo Akademii Ekonomicznej, Katowice. 
11. Kuo-Huie Chiang J., Hung-Yue S. (2015), Self-presentation and hiring recommendations in online communities: Lessons from LinkedIn, "Computers in Human Behavior", Vol. 48, pp. 516-524.

12. Leary M. (1999), Wywieranie wrażenia na innych. O sztuce autoprezentacji, GWP, Gdańsk.

13. Lievens F., Peeters H. (2008), Interviewers' sensitivity to impression management tactics in structured interviews, "European Journal of Psychological Assessment", Vol. 24 (3), pp. 174-180.

14. Łodziński, S. (2003), Problemy dyskryminacji osób należących do mniejszości narodowych $i$ etnicznych $w$ Polsce (polityka państwa, regulacje prawne i nastawienia społeczne, Kancelaria Sejmu, Biuro Studiów i Ekspertyz, Wydział Analiz Ekonomicznych i Społecznych, http://biurose.sejm.gov. pl/teksty_pdf_03/r-219.pdf (10.07.2015 - date of access).

15. Rusak P, Wizerunek $w$ sieci - daj się znaleźć pracodawcy, content.pracuj.pl/ ebook_Ewizerunek.pdf (15.05.2015 - date of access).

16. Sackett P., Lievens F. (2008), Personnel selection, "Annual Review of Psychology", Vol. 59, pp. 419-450.

17. Stankiewicz J., Bortnowska H. (2016), Wizerunek zawodowy studentów na rynku pracy w świetle badań empirycznych, Wrocław, in press.

18. Szewczyk A. (2011), Popularność funkcji serwisów społecznościowych, Zeszyty Naukowe Uniwersytetu Szczecińskiego, No. 656, „Studia Informatica”, No. 28, Wydawnictwo Naukowe Uniwersytetu Szczecińskiego, pp. 381-395.

19. Szmajke A. (2001a), Autoprezentacja - niewinny spektakl dla innych i siebie, [in:] M. Kofta, T. Szutrowa (eds.), Złudzenia, które pozwalaja żyć: Szkice ze społecznej psychologii osobowości, PWN, Warszawa, pp. 146-175.

20. Szmajke A. (2001b), Autoprezentacja: formy, style, skuteczność interpersonalna, [in:] K. Lachowicz-Tabaczek (ed.), Psychologia społeczna w zastosowaniach. Od teorii do praktyki, Atla2, Wrocław, pp. 147-183.

21. Szreder M. (2004), Metody i techniki sondażowych badań opinii, PWE, Warszawa.

22. Wieman W. (2009), Prześwietla Cie w Internecie, http://www.newsweek. $\mathrm{pl} /$ przeswietla-cie-w-internecie,46549,1,1.html (13.07.2015 - date of access).

23. Włodarczyk J. (2014), Mowa nienawiści w Internecie w doświadczeniu polskiej młodzieży, "Dziecko krzywdzone. Teoria, badania, praktyka”, Vol. 13 (2), pp. 122-158.

24. Wosińska W. (2004), Psychologia życia społecznego. Podręcznik psychologii społecznej dla studentów i praktyków, GWP, Gdańsk. 